\title{
Currency Depreciation Nexus Country's Export: Evidence from Georgia
}

\author{
Azer Dilanchiev ${ }^{1, *}$, Tengiz Taktakishvili ${ }^{2}$ \\ ${ }^{1}$ Department of Economics, International Black Sea University, Tbilisi, Georgian Republic \\ ${ }^{2}$ Department of Business Administration, Georgian National University, Tbilisi, Georgian Republic
}

Received July 20, 2021; Revised September 1, 2021; Accepted September 21, 2021

\begin{abstract}
Cite This Paper in the following Citation Styles
(a): [1] Azer Dilanchiev, Tengiz Taktakishvili, "Currency Depreciation Nexus Country's Export: Evidence from Georgia," Universal Journal of Accounting and Finance, Vol. 9, No. 5, pp. 1116 - 1124, 2021. DOI: 10.13189/ujaf.2021.090521.
\end{abstract}

(b): Azer Dilanchiev, Tengiz Taktakishvili (2021). Currency Depreciation Nexus Country's Export: Evidence from Georgia. Universal Journal of Accounting and Finance, 9(5), 1116 - 1124. DOI: 10.13189/ujaf.2021.090521.

Copyright $\bigcirc 2021$ by authors, all rights reserved. Authors agree that this article remains permanently open access under the terms of the Creative Commons Attribution License 4.0 International License

\begin{abstract}
The recent shocks in demand and supply caused by Covid-19 influence and the current depreciation of the Georgian Lari (GEL) reduced the trust of economic agents in currency. There is no objective macroeconomic reason that would change their attitude to the future of currency for the better. Depreciation of a currency impacts all the components of GDP, leading to myriad problems in economic growth. The depreciation of the national currency is generally perceived as positively affecting the country's export. The study analyzes the impact of Georgian Lari's exchange rate depreciation on Georgia's export using monthly GEL exchange rate data from May 2006 to April 2020. The paper employs Autoregressive Distributed Lag Model (ARDL) for its advantages of measuring cointegration, usefulness in the small samples, and being unbiased in measuring a long-run relationship between variables. Outcomes indicate that the exchange rate depreciation has an inverse long-run impact on export in the long-run period. The exchange rate impact on Georgia's export shows inelastic demand for Georgia's export goods. The study contributes to the literature while providing the implication of currency depreciation on exports of the Georgian economy. The estimated value of the exchange rate has been found to exert no direct pressure on the amount of export. In the paper, possible reasons for such implications are also examined. Paper found that the control variable interest rate also has an inverse impact on Georgia's export performance in the long-run as well as in the short-run. International reserves positively influence the export in the long-run with a high
\end{abstract}

significance level. The paper also discusses possible ways of stabilization of national currency.

Keywords Exchange Rate, Currency Depreciation, Export, International Trade, Interest Rate

\section{Introduction}

Depreciation of the exchange rate has been one of the academics and financial analysts' most up-to-date issues. The National Bank of Georgia's key concern is that its monetary interventions control the exchange rate.

The current depreciation of the Georgian Lari (GEL) reduced the trust of economic agents in currency. There is no objective reason that would change their attitude to the future of currency for the better. Depreciation of a currency impacts all the components of GDP, leading to myriad problems in economic growth.

The recent shocks in demand and supply caused by Covid-19 influence exchange rates, affecting inflation, interest rates, foreign trade, and other macroeconomic variables. Also, these shocks cause economic uncertainty, which is another reason for exchange rate fluctuations. The National Bank of Georgia made more than 20 interventions in 2020, trying to stabilize the currency, and these interventions are to be continued in the first part of 2021. As foreign currency inflow to Georgia decreased considerably, these interventions must somehow stop 
GEL's depreciation. Georgia's monetary structure is floating, and it is characterized by short-term volatility, and is mainly shaped by the foreign exchange market. The exchange rate trend between USD and GEL is given in Table 1, showing a drastic depreciation in the period of 2014-2019.

The balance of the GEL change rate is vital for the long-time period monetary improvement of the country. Most of Georgia's public debt is in foreign currency, which is another issue for concern when the currency depreciates. Among the factors affecting the exchange rate of GEL are foreign investments, the volume of GEL in the country, and households and businesses' expectations towards the exchange rate fluctuations. As Georgia is an import-dependent country, currency depreciation severely affects its economy. Exchange rate depreciation leads to market uncertainty, the volatility of incomes for exporters and importers.

One difficulty in this area is to consider how the export of a nation is impacted. The restriction of tourism, a critical source of currency inflow, is another explanation for this. If this pattern progresses, even tougher pressures on GEL can be expected. Investigations into the effect of depreciation on the exports of a nation have a long history. For decades, the notion that the weakening of the nation's currency has a beneficial impact on exports was one of the most popular economic literature concepts.

When the currency depreciates, products produced domestically become cheaper for foreigners. They can buy more of these products, so the volume of export increases has a favorable effect on the net export. Although, in the case of Georgia, this study found an inverse relationship. The study has increasingly grown as more analysts examine the exchange-rate-export relationship. Some found adverse effects of fluctuations in exchange rates on exports while others did not.

Export is a crucial element of international trade in promoting economic globalization that makes developing countries more integrated with the world economy and ensures that economic well-being is distributed equally among nations. Many governments worldwide support exporting industries because of their ability to create jobs and support countries to acquire new technologies. About
$70 \%$ of international trade is currently accomplished through the global value chains (GVCs), meaning that materials, parts, and components are moving across the borders (OECD). The volume of international trade has considerably increased in the last decades; however, the COVID-19 pandemic caused a drastic fall. Exports of G20 declined by $17.7 \%$ in the second quarter of 2020 relative to the first, the highest fall since 2007-2008. China was the only G-20 nation not affected by the export decline; export growth in the second quarter of 2020 also saw a 9.1 percent growth (OECD). The current pandemic also affected Georgia's export. As Georgia mainly exports intermediary goods (about $30 \%$ of Georgia's exports come to Copper ores and Ferro-alloys), it is dependent on the production capacities abroad.

Restrictions imposed in foreign countries worldwide shrank production volume and supposedly will drop demand on intermediary goods further. It is worth mentioning that around $12 \%$ share is occupied by re-exporting motor cars in Georgia's export. As this business is also heavily affected by the pandemic, demand for these goods in foreign markets has sharply declined. Last year's essential advances happened to Georgia's international trade. Export markets for Georgian products became more differentiated, caused by instabilities on the Russian market and the need to find alternative markets in the EU and China. Similarly, Georgia managed to agree about the Deep and Comprehensive Free Trade Area with the EU and China's Free Trade Agreement. Figure 2 below shows the data regarding export from Georgia from 2006 to 2020.

The paper employs Autoregressive Distributed Lag Model (ARDL) for its advantages of measuring cointegration, usefulness in the small samples, and being unbiased in measuring a long-run relationship between variables. The study utilizes monthly aggregate data for the period of May 2006 - April 2020 and is extracted from the National Bank of Georgia (NBG) database. The study's findings will allow policymakers in Georgia to consider the effect of currency volatility on exports. The paper's results are also impressive for Georgian exporters and help them prepare and further predict their foreign activities. 
EX

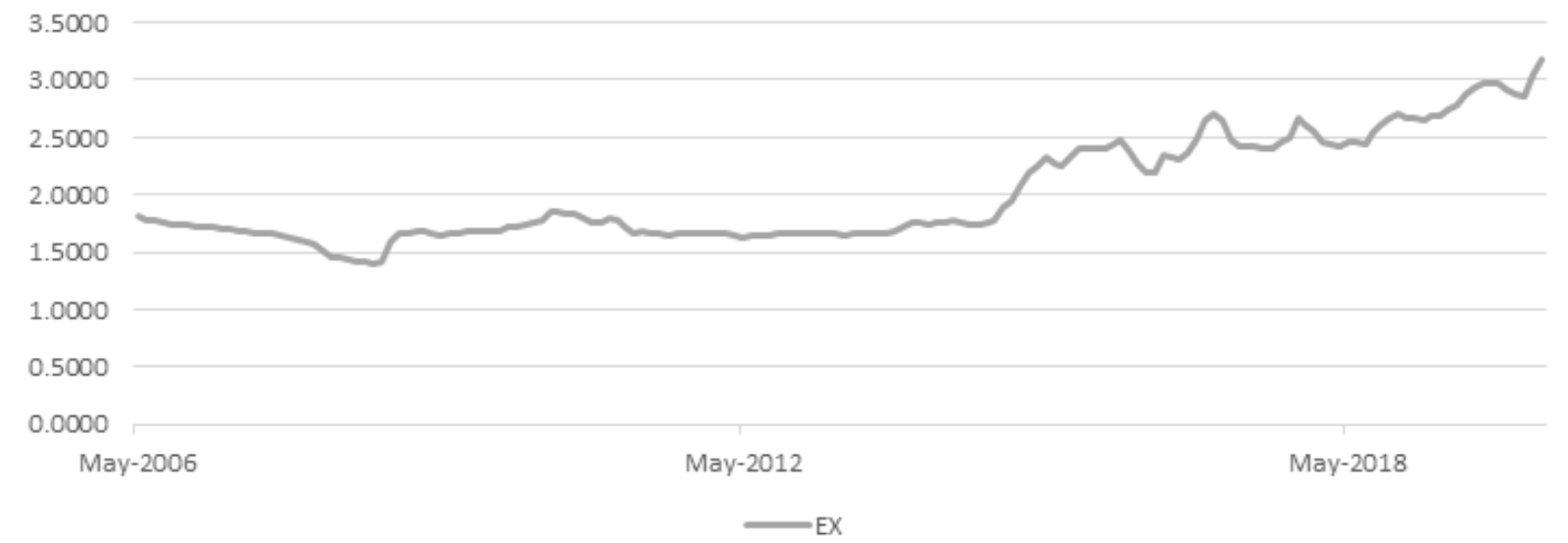

Figure 1. Exchange rate (EX) trend between USD and GEL. (Source: National Bank of Georgia)

$$
\text { EXP }
$$

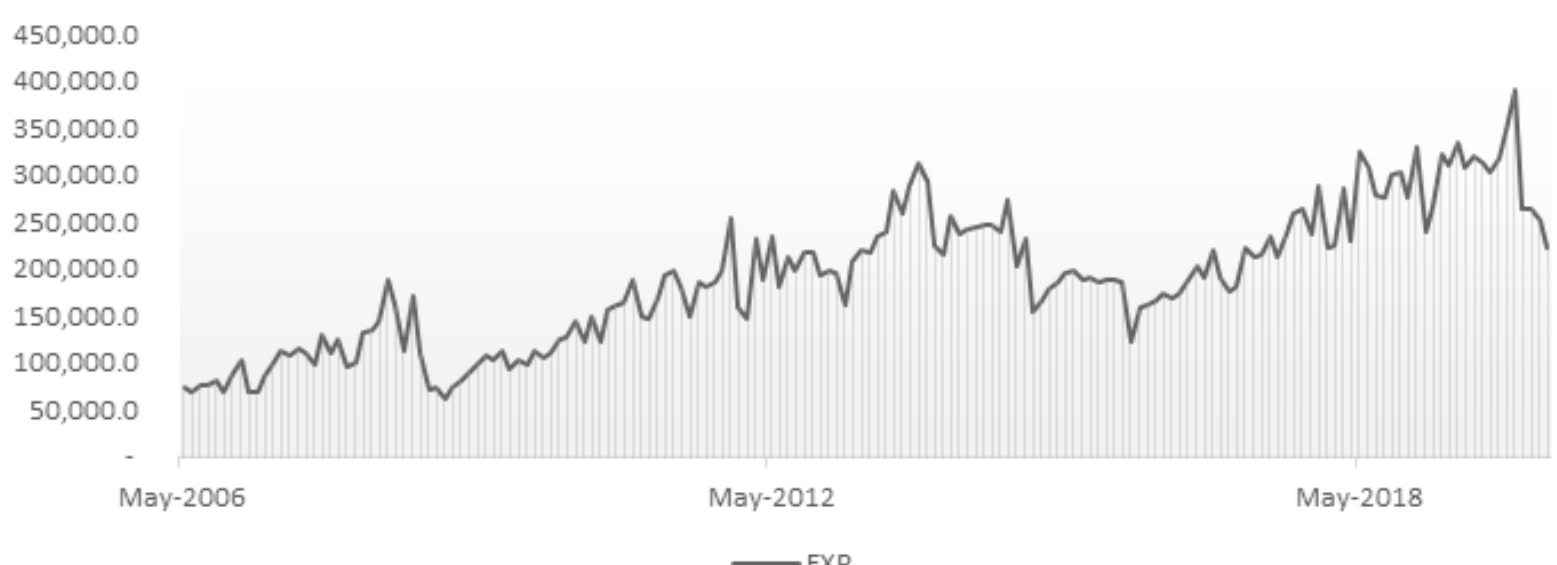

Figure 2. Export (EXP) from Georgia by years. (Source: The National Statistics Office of Georgia) 


\section{Literary Review}

A large volume of literature exists that analyses the effect of the exchange rate on export. Some empirical researchers have argued for the adverse impact of volatility on exports; others have argued for positive or no effects at all. However, the majority of the works support a traditional view that exchange rate depreciation positively influences export (Connolly \& Taylor, 1972), (Junz \& Rhomberg, 1973), (Bahmani-Oskooee \& Kara, 2008), (Thorbecke, 2008), (Yildiz, Ide, \& Malik, 2016). Some authors found controversial results. The authors (Olugbenga \& Oluwole, 2008), in the study of the links between exchange rate fluctuation and export growth, based on cointegration and the Vector Error Correction Model method in Nigeria, has shown that real-world exchange fluctuations generate uncertainty about profit opportunities, leading to significant adverse effects on exports both in the long and short term.

Aftab et.al (Aftab, Abbas, \& Kayani, 2012) found out that instability in exchange rates has a negative impact on Pakistan sectorial exports, with the particular case of waxes and creature oils, flying machine, implyingtransport and weapons, but appearing signs of a negative relationship. The relative cost moreover appears to a negative association for all segments. With the exemption of creatures and vegetables, materials and materials were negative. A negative sign demonstrates that the decay in trade request is related to an increment within the relative cost.

Nyeadi et al. (Nyeadi, Atiga, \& Charles, 2014) observed that the exchange rate shift did not affect exports in Ghana's case by using the OLS method.

Ahmed et al. (Ahmed, Qasim, \& Chani, 2017) using the annual time series data from 1970 to 2015 evaluated an impact on export in Pakistan's case. It investigated the exchange rate effect. The authors employ the ARDL model for assessing the relation between selected variables in the study. The paper shows that the volatility of an exchange rate negatively yet negligibly affects exports' net quantity. In the case of Armenia, Barseghyan and Hambardzumhyan (Barseghyan \& Hambardzumyan, 2017) analyzed how the exchange rate volatility influences Armenia's export with its leading trading partner in the 2007 to 2016 time period, and they found a significant adverse effect that volatility of exchange rate has in the short-run and in the long-run on export.

Thuy and Thuy (Thuy \& Thuy, 2019), while analyzing how export is affected by the volatility of exchange rate, employing the (ARDL) bounds testing approach, in the case of Vietnam, found that depreciation of the domestic currency adversely impacts exports in the short-run, but favorably in the long-run. Dincer and Kandil (Dincer \& Kandil, 2010) studied the effect of shifts in exchange rates on several export sectors in Turkey. Based on the theory of exchange rate volatility, the findings were established through demand and supply networks in the empirical investigation and split into projected and unforeseen components. The authors noted the asymmetrical effects on the growth of export in the sector of random currency fluctuations. Analysis reveals a positive transformation shock, an unintended strengthening of the domestic currency, lower net exports, and greater demand. The study indicates that the growth in export demand is likely to increase the currency over time, with depreciation having lost momentum due to the rise in export demand.

Yunusa (Yunusa, 2020) studied the influence of exchange rate volatilities on Nigerian crude oil exports in their trading partner countries. Author usesARDL and demonstrates that the instability of exchange rates significantly impacts Nigeria's raw oil exports. The study measured the influence of the fluctuations of the exchange rate by the ARDL process. The findings show that, regardless of actual exchange rate shifts, only 2 in 7 countries have a short-term influence on Nigeria's exports. The long-term findings indicate that Nigeria's uncertainty as a trading partner is statistically significant for any trading partner, albeit to a different extent.

The effect on Indonesia's top five export destinations on exports of export goods was estimated as a result of variations in the exchange rate by Sugiharti et al. (Sugiharti, Esquivias, \& Setyorani, 2020). The approximate GARCH Model value of the exchange rate models ARDL and NARDL was used for observational analysis. The findings show that the uncertainty in the exchange rate has a significant effect on commodities exports. The adverse impact of exchange rate fluctuations on Indonesian exports is indicated by both the ARDL and NARDL models. Each of the top trading partners in Indonesia is calculated separately.

Senadza and Diaba (Senadza \& Diaba, 2018) used GARCH-generated substitutes for exchange rate fluctuations and GARCH models. They showed a negative short-run influence of volatility on exports but a positive long-run effect.

\section{Data and Methodology}

\subsection{Data}

The paper explores the relationship between export and exchange rate depreciation in Georgia; interest rate and foreign reserves were selected as macroeconomic control variables. Variables were selected based on economic theory; however, some of the variables were excluded due to data unavailability. This study's monthly aggregate data span from 2006 May to 2020 April and are extracted from the National Bank of Georgia (NBG) database. The paper expresses Georgia's Export model as follows:

$$
L E X P_{t}=f\left(L E X, L R_{t}, L R E S_{t}\right)
$$

$L E X P$ represents export, $L R$ represents interest rate, $L E X$ is the monthly average exchange rate, and LRES is 
the amount of foreign reserves in USD. All variables are taken in the natural logarithm form.

\subsection{Model Specification}

In the study, the Peseran et al. (Pesaran, Yongcheol, \& Smith, 2001) ARDL bound test was used to measure cointegration and a long-term relationship between variables. The ARDL method of cointegration estimation gives the benefits of the test, no matter the variables are I(0) or I. Furthermore, according to Narayan and Paresh (Narayan, 2005) ARDL approach is advantageous in the small samples and Harris, and Sollis, (2003) (Harris \& Sollis, 2003) indicate the importance of ARDL method as being unbiased in measuring long-run relations between variables. While analyzing the literature, Engle and Granger's (Engle \& Granger, 1987)cointegration tests are widely used methods for measuring long-run cointegration. However, these methods have some limitations. All variables have to be stationary at the first level or exclude multivariate analysis under Engle and Granger method and lag selection sensitivity issue in the Johansen Co-integration test (Johansen, 1988). The estimated ARDL model specified below captures long-run and short-run:

$$
\begin{aligned}
\Delta L E X P_{t}=\alpha_{0} & +\alpha_{1} L E X P_{t-1}+\alpha_{2} L E X_{t-1}+\alpha_{3} L R_{t-1} \\
& +\alpha_{4} L R E S_{t-1}+\sum_{i 1=1}^{p} \beta_{1 i} \Delta L E X P_{t-i 1} \\
& +\sum_{\substack{i 2=1 \\
y}}^{q} \beta_{2 i} \Delta L E X_{t-i 2}+\sum_{i 3=1}^{v} \beta_{3 i} \Delta L R_{t-i 3} \\
& +\sum_{i 4=1}^{y} \beta_{4 i} \Delta L R E S_{t-i 4}+\varphi E C T_{t-1}+\epsilon_{t}
\end{aligned}
$$

Where $\Delta$ is the first difference operator and $p, q, v, y$ are optimal lags in the model, $\alpha$ and $\beta$ are coefficients $\varphi$ is the coefficient of the error correction term (ECT) which measures the speed of adjustment to equilibrium ( $\varphi$ should be negative and below the 1) and $\varepsilon_{\mathrm{t}}$ is a white noise disturbance error term, the remaining symbols were described previously. Based on the Walt test, F-statistics cointegration among variables were tested where the null hypothesis indicates no integration among the variables. In contrast, the alternative hypothesis suggests the presence of integration among variables.

$$
\begin{aligned}
& H_{N}: \beta_{1}=\beta_{2}=\beta_{3}=\beta_{4}=0 \\
& H_{A}: \beta_{1} \neq \beta_{2} \neq \beta_{3} \neq \beta_{4} \neq 0
\end{aligned}
$$

Following Pesaran, if F-statistic is above the lower and higher critical values, then it is possible to conclude that there is cointegration among the variables. However, if the F-statistic value is below the lower critical value, it is possible to conclude no cointegration in the series. The need for other cointegration tests appears when the F-statistics value is between higher and lower bounds, which creates uncertainty about the level of cointegration.

\section{Empirical Results}

\subsection{Unit Root Test}

The findings of the Augmented Dickey-Fuller (ADF) and Phillips-Perron (PP) unit root tests based on the Schwarz information criterion (SIC) are expressed in table 1. The ADF result indicates that variables household consumption is not stationary at the level. Simultaneously, savings and inflation are stationary at the level, and the GDP per capita growth rate is stationary at $10 \%$. In the first difference, household consumption becomes stationary, and GDP per capita growth rate also becomes stationary at $5 \%$. Phillips-Perron (PP) unit root test results show that all variables are not stationary at a level except inflation, which is stationary at $1 \%$. At the first difference, all variables are stationary at a $1 \%$ significance level. The combination of stationary variables in level $\mathrm{I}(0)$ and in the first difference I(1) makes an ARDL bound test method optimal for the analysis's estimation procedure.

Table 1. Unit root test for stationarity

\begin{tabular}{ccccc}
\hline & ADF & & PP \\
\hline Variables & Level & First difference & Level & First difference \\
\hline LEXP & -2.4179 & $-18.4115^{* * *}$ & -2.4744 & $-22.6331^{* * *}$ \\
LEX & 0.1310 & $-7.8405^{* * *}$ & 1.1437 & $-7.2386^{* * * *}$ \\
LR & -0.2404 & $-14.3435^{* * *}$ & -0.8137 & $-18.9655^{* * *}$ \\
LRES & $-3.9378^{* * *}$ & & $-4,5880^{* * *}$ & -3.4699 \\
$\mathbf{1 \%}$ & -3.4699 & -3.4699 & -3.4696 & -2.8788 \\
$\mathbf{5 \%}$ & -2.8788 & -2.8788 & -2.8787 & -2.5760 \\
\hline $\mathbf{1 0 \%}$ & -2.5760 & -2.5760 & -2.5760 & \\
\hline
\end{tabular}

Notes: *** Significant at $1 \%, * *$ Significant at $5 \%, *$ Significant at $1 \%$ 


\subsection{Cointegration Procedure}

The second equation (Eq2) bound test identifies the cointegration between dependent and independent variables. The ARDL model is selected with $(2,1,1,4)$ lag order (based on Akaike info Criterion (AIC) with maximum dependent lags 4) where the savings(LRES) has the maximum lag of 4 . The dependent variable (LEXP) lagged 2 times, and (LEX), (LR) lagged 1 time.

Table 2 indicates the cointegration test results:

Table 2. F statistics and bound test

\begin{tabular}{ccccccc}
\hline Model & k & M & F statistics & $\begin{array}{c}\text { Significance } \\
\text { level }\end{array}$ & $\begin{array}{c}\text { Lower } \\
\text { bound }\end{array}$ & $\begin{array}{c}\text { Upper } \\
\text { bound }\end{array}$ \\
\hline & & & & $10 \%$ & 2.37 & 3.2 \\
ARDL & 3 & 4 & $6.333036^{*}$ & $5 \%$ & 2.79 & 3.67 \\
$(2,1,1,4)$ & 3 & & & $1 \%$ & 3.65 & 4.66 \\
\hline
\end{tabular}

Notes: $\mathrm{M}$ indicates maximum lags, $\mathrm{k}$ expresses explanatory variables, and $*$ indicates a $1 \%$ level of significance.

F statistic result confirms cointegration between dependent and independent variables in the model. In all levels, the $\mathrm{F}$ statistic appears to be higher than the upper bound critical values.

\subsection{Empirical Results for the Long-Run and Short-Run Periods}

The outcomes of the long-run and short-run estimations are presented in Table 3.

Table 3. Estimated ARDL $(1,4,2,0)$ Long-run model

\begin{tabular}{ccc}
\hline Variable & Coefficient & t-Statistic \\
\hline LEX & -1.128452 & $-4.228035^{* * *}$ \\
LR & -1.753426 & $-5.979000^{* * *}$ \\
LRES & 0.673169 & $8.157450^{* * *}$ \\
C & 3.444765 & $4.424463^{* * *}$ \\
\hline
\end{tabular}

Notes: *** Significant at $1 \%, * *$ Significant at $5 \%, *$ Significant at $1 \%$

Results in Table 3 shows a long-run relationship between export (LEXP) and independent variables (LEX, LR, LRES) with a high statistical significance level.
Table 4. Estimated ARDL $(1,4,2,0)$ Short-run model

\begin{tabular}{ccc}
\hline Variable & Coefficient & t-Statistic \\
\hline ECT(-1) & -0.430977 & $-5.700743^{* * *}$ \\
D(LEXP(-1)) & -0.191403 & $-2.792111^{* * *}$ \\
D(LEX) & -1.825230 & $-4.310336^{* * * *}$ \\
D(LR) & -1.134963 & $-5.682792^{* * *}$ \\
D(LRES) & 0.360764 & $2.264226 * *$ \\
D(LRES(-1)) & -0.478774 & $-2.866198^{* * *}$ \\
D(LRES(-2)) & -0.169704 & -1.060770 \\
D(LRES(-3)) & 0.274726 & $1.703885^{*}$ \\
\hline
\end{tabular}

Notes: *** Significant at $1 \%$, ** Significant at $5 \%, *$ Significant at $1 \%$

\section{Diagnostic Tests}

Result tests are summarized in table 5. A widely used checking for serial correlation Breusch-Godfrey Serial Correlation LM Test did not show any serial correlation in the model. The Breusch-Pagan-Godfrey test is used to check heteroskedasticity. The tests' results indicate no heteroskedasticity or, in other words, the variance is constant in the residuals. The test does not reject the null hypothesis of no heteroskedasticity at $0.05 \%$ level. We checked the normality of the residuals by the Jarqua-Bera test (JB). The test results cannot reject the null hypothesis, which indicates that residuals are normally distributed. The Ramsey Reset test confirmed that the model is correctly specified since the probability result of the test, $70.34 \%$, is more than $5 \%$ significance level. The empirical results revealed that the ARDL model used in the analysis passed all diagnosis tests successfully.

Table 5. Test Statistics

\begin{tabular}{ccll}
\hline $\mathrm{X}_{\text {BG }}^{2}$ & $0.220188(0.8026)$ & $\mathrm{X}_{\mathrm{JB}}^{2}$ & $0.415397(0.8124)$ \\
$\mathrm{X}_{\text {BPG }}^{2}$ & $1.515255(0.1312)$ & $\mathrm{X}_{\text {Ramsey }}^{2}$ & $0.352655(0.7034)$ \\
\hline
\end{tabular}

Notes: $x^{2} B G$ is the Breusch-Godfrey Serial Correlation LM Test used to check serial correlation, $x^{2} \mathrm{BPG}$ is the Breusch-Pagan-Godfrey test used to check heteroskedasticity, $x^{2} \mathrm{JB}$ is the Jarqua-Bera test used to check the normality, and $x^{2}$ Ramsey used to check whether the model correctly specified.

For checking the stability of the model, QUSUM and a QUSUMSQ test have been conducted. The stability test results are presented in Figure 3 and Figure 4. The test results indicate that plots of both stability tests are between critical boundaries at a 5\% significance level. 


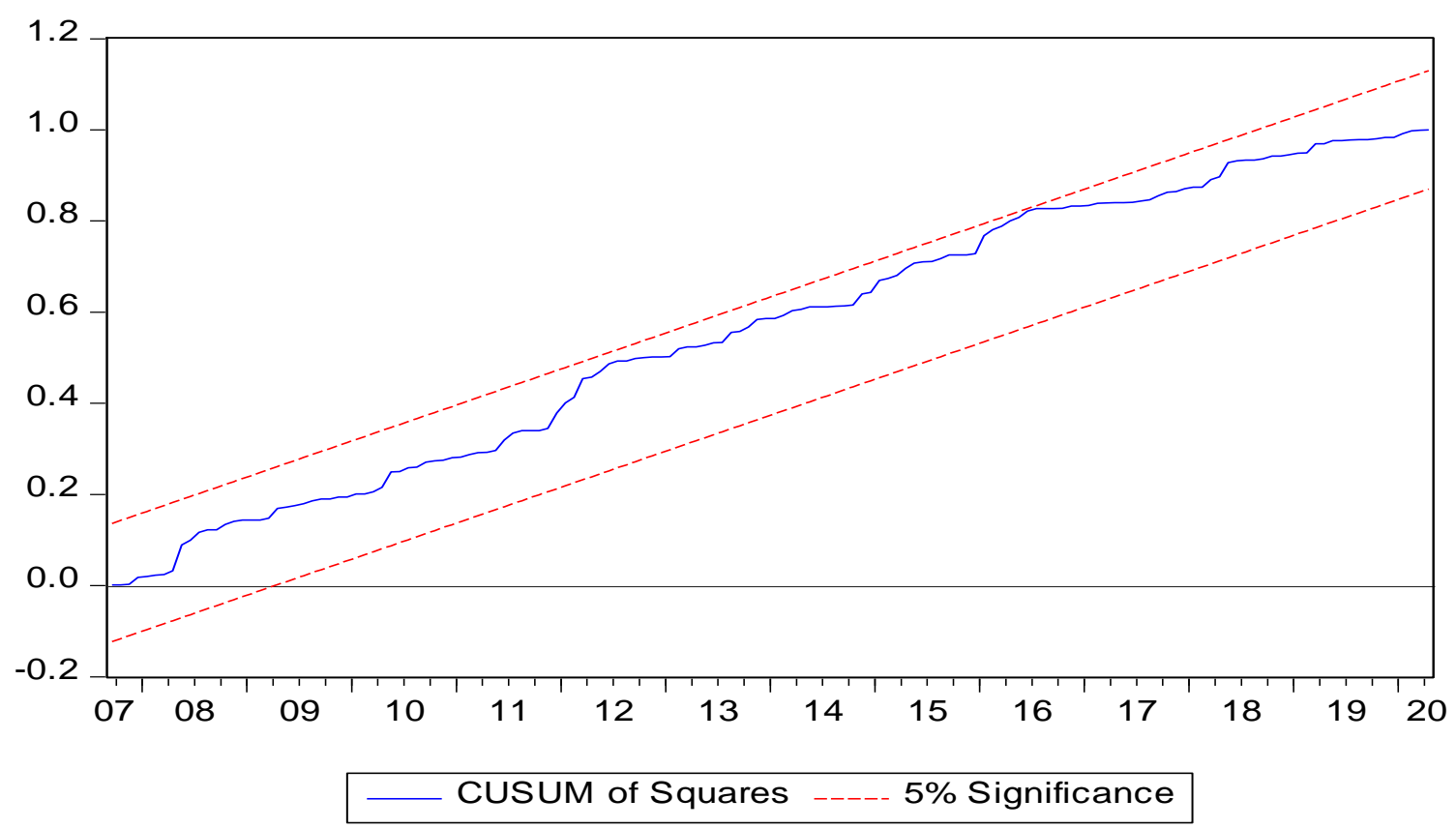

Figure 3. QUSUMSQ test Result of ARDL $(2,1,1,4)$ model.

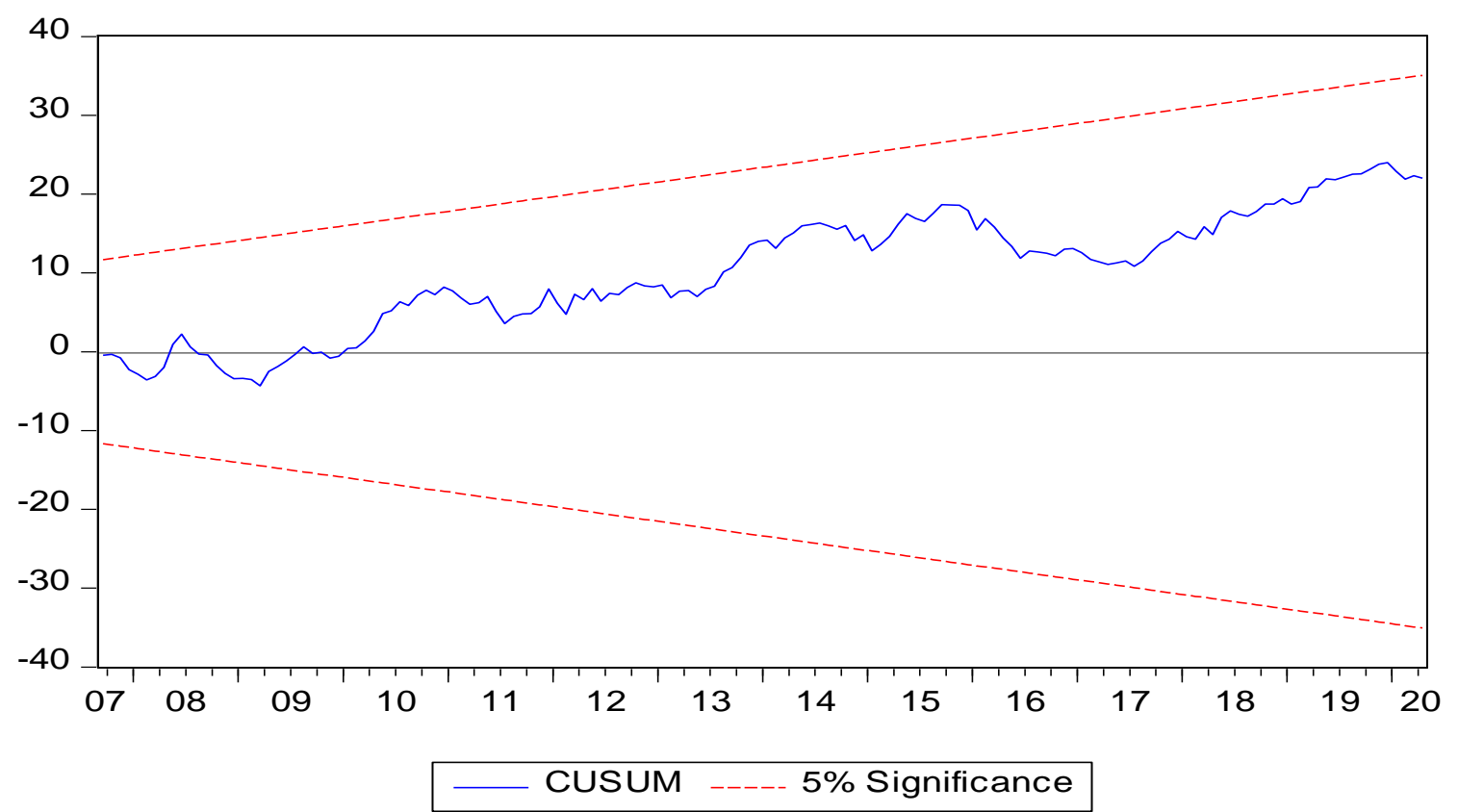

Figure 4. QUSUM test Result of $\operatorname{ARDL}(2,1,1,4)$ model.

\section{Discussion}

The paper's results cast a new light on the exchange rate's impact on Georgia's export performance. From the results, it is evident that in the long term period, the exchange rate depreciation (LEX) has an inverse long-run effect on export (LEXP), which confirms the absence of $\mathrm{J}$-curve in the long-run in Georgia. Based on the J-curve theory, as the domestic currency's value depreciates, it causes a particular assumption to decrease import and export, but in the long-term export boosts, which is not valid for our case results. The negative long-run influence of exchange rate depreciation on Georgia's export can be associated with an increase in the cost of input caused by domestic currency depreciation and inflation. Based on the theory, the devaluation of the exchange rate leads to an increase in export by making domestic products cheaper for foreigners; however, it is linked with the elasticity of the demand for export in a given country. If export demand elasticity is more than unity in a country, the exchange rate's devaluation positively influences exports. Another reason is that the Georgian economy highly relies on importing raw materials involved in producing goods for export; the devaluation of the 
exchange rate makes these goods expensive and raises the cost, negatively influencing export. The inverse impact of the exchange rate on Georgia's export confirms that Georgia's export goods' demand elasticity is less than the unity. The exchange rate measured coefficient is -1.12 percent, implying that the exchange rate negatively impacts export, meaning that the exchange rate depreciation negatively influences the export volume in Georgia's case in the long-run (Table 3). The estimated long-run results show that if the exchange rate increases by $1 \%$ (devaluation by $1 \%$ ), the export will decrease by $1.12 \%$ in the long-run. In the short-run, the results also indicate a negative relationship between exchange rate and export, so the exchange rate measured coefficient is -1.82 percent (Table 4).

Overall these findings are following theoretical models of export reported by Fang, Lai, and Miller (Fang, Lai, \& Miller, 2005) that report the negative effect of the exchange rate may dominate over the positive contribution of currency depreciation, thus decreasing the export. Mukesh et al. (Mukesh \& Azeema, 2020) analyzed the South Asian Economies found that currency depreciation reduces the export in the long-run in the four SAARC countries - Bangladesh, India, Pakistan, and Sri Lanka. They reported that in 13 countries, the exchange rate volatility negatively influences the export. The control variable interest rate (LR) negatively affects Georgia's export performance in the long-run (-1.75) and the short-run(-1.13), (Tables 3-4). The long-run 1\% increase in the interest rate causes the export to decrease by $1.75 \%$, while the short-run $1 \%$ increase in the interest rate leads to a decrease in export by $1.13 \%$. The increase in the interest rate makes financial sources (credits, bank loans) expensive, which increases the cost of production for the exporters, thus affecting the export negatively. Interest rate fluctuations also lead to changes in the exchange rate, leading to changes in net exports. International reserves positively influence the export in the long-run with a high significance level. The $1 \%$ increase in Georgia's international reserves causes a $0.67 \%$ increase in the export. The error correction term (ECT) is negative, significant, and between 0 and $1(-0.43)$, which confirms the model's reliability (Table 4 ). The findings are following Polterovich et al. (Polterovich, Pavlov, Polterovich, \& Popov, 2006) works. According to NBG, Georgia's international reserves in 2019 reached the historic level of $\$ 3.74$ billion (Georgia, 2020). The increase in international reserves is essential for sustainable macro-financial stability. Starting from 2014, the NBG uses part of its reserves to avoid domestic currency fluctuation, positively influencing the export.

\section{Conclusion}

The paper pointed at uncovering the potential impact of the exchange rate of GEL on Georgia's exports. Depreciation of GEL is among the current issues facing the country's economy. Hence, it analyzes how this trend relates to the country's export and whether it is according to the literature's prevalent findings of the positive impact of currency depreciation on a country's export. The results complement the existing evidence about such effects in the economic literature.

Recent fluctuations in the exchange rate may be attributed to the considerable reduction of foreign currency inflows (reduced foreign investments and the number of tourists) and reduced trust towards the national currency in Georgia's population. The results of the paper indicated that in the long-run, depreciation of the exchange rate (LEX) negatively affects export (LEXP), while interest rate (LR) also negatively affects Georgia's export performance in both the long-run and the short-run. On the contrary, international reserves positively impact the export in the long-run with a high significance level. The findings of the paper that indicate the negative effect of exchange rate depreciation on export enables us to infer that in the case of Georgia, industries are producing goods for export use inputs that are imported, and currency depreciation makes them even expensive, so the price of exported goods will not decrease. The National Bank of Georgia should track and enforce policies to stop the GEL's fluctuation in the foreign exchange market. Monetary measures are not appropriate but necessary for this reason.

On a broader policy level, the government can consider tax incentives for foreign investors and the implementation of large projects like the Port in Anaklia. Without such large-scale projects, the balance between GEL and foreign currencies will not be stabilized on an exchange market. The paper contributes to the studies on the impact of exchange rates on exports for Georgia and stresses the importance of stabilizing the national currency. As a widely accepted assumption in the economic literature about a positive impact of currency depreciation on export did not appear to be true for Georgia, it is crucial to tackle the challenge of depreciating national currency. The study's future directions should focus on how currency depreciation affects export by product groups and Georgia's trading partners. That would provide important insights for companies doing exports and help them to better plan their international operations.

\section{REFERENCES}

[1] M. Connolly and D. Taylor, "Devalution in Less Developed Countries," in The Effects of Exchange Rate Adjustments, Washington. DC, 1972.

[2] H. B. Junz and R. R. Rhomberg, "Price Competitiveness in Export Trade Among Industrial Countries," American Economic Review, vol. 63, no. 2, pp. 412-418, May 1973. 
[3] M. Bahmani-Oskooee and O. Kara, "Relative Responsiveness of Trade Flows to a change in Prices and Exchange rate," Journal of Economic Development, vol. 33, no. 1, pp. 147-163, 2008.

[4] W. Thorbecke, "The effect of exchange rate volatility on fragmentation in East Asia: Evidence from the electronics industry," Journal of the Japanese and International Economies, vol. 22, no. 4, pp. 535-544, 2008.

[5] H. Y1ld1z, G. Ide and S. Malik, "The Relationship between Exchange Rate Volatility and Economic Growth: An Example of Turkey," International Journal of Arts and Commerce, pp. 47-61, 2016.

[6] A. O. Olugbenga and O. Oluwole, "Exchange rate volatility and export growth in Nigeria," Applied Economics, vol. 40, no. 12, pp. 1547-1556, 2008.

[7] M. Aftab, Z. Abbas and F. Kayani, "Impact of exchange rate volatility on sectoral exports of Pakistan: An ARDL investigation," Journal of Chinese Economic and Foreign Trade Studies, vol. 5, no. 3, pp. 215-231, 2012

[8] J. D. Nyeadi, O. Atiga and A. Charles, "The Impact of Exchange Rate Movement on Export: Empirical Evidence from Ghana," International Journal of Academic Research in Accounting, Finance and Management Sciences, vol. 4, no. 3 , pp. $41-48,2014$.

[9] K. Ahmed, M. Qasim and M. I. Chani, "Impact of Exchange Rate on Exports in Case of Pakistan," Bulletin of Business and Economics, vol. 6, no. 2, pp. 98-102, 2017.

[10] G. Barseghyan and H. Hambardzumyan, "The effects of exchange rate volatility on exports: evidence from Armenia," Applied Economic Letters, vol. 25, no. 18, pp. 1266-1268, 24102017.

[11] V. Thuy and D. Thuy, "The Impact of Exchange Rate Volatility on Exports in Vietnam: A Bounds Testing Approach," Journal of Risk and Financial Management, vol. 12, no. 1, p. p6, January 2019.

[12] N. Dincer and M. Kandil, "The effects of exchange rate fluctuations on exports: A sectoral analysis for Turkey," The Jounral of International Trade and economic Development, vol. 20, no. 6, pp. 809-837, 2010.
[13] L. Yunusa, "Exchange rate volatility and Nigeria crude oil," Scientific African, vol. 9, p. e00538, 2020.

[14] L. Sugiharti, M. Esquivias and B. Setyorani, "The impact of exchange rate volatility on Indonesia's top exports to the five main export markets," Heliyon, vol. 6, no. 1, pp. e031413 1-14, 2020

[15] B. Senadza and D. Diaba, "Effect of exchange rate volatility on trade in SubSaharan Africa," Journal of African Trade, vol. 4, no. 1-2, pp. 20-36, 2018.

[16] H. M. Pesaran, S. Yongcheol and R. Smith, "Bounds testing approaches to the analysis of level relationships," Journal of Applied Econometrcis, vol. 16, no. 3, pp. 289-326, 2001

[17] K. P. Narayan, "The saving and investment nexus for China: evidence from cointegration tests," Applied Economics, vol. 37, no. 17, pp. 1979-1990, 2005.

[18] R. Harris and R. Sollis, Applied Time Series Modelling and Forecasting, 2003

[19] R. Engle and C. Granger, "Co-Integration and Error Correction: Representation, Estimation, and Testing," Econometrica, vol. 55, no. 2, p. 251-276, 1987.

[20] S. Johansen, "Statistical analysis of cointegration vectors," Journal of Economic Dynamics and Control, vol. 12, no. 2-3, pp. 231-254, 1988.

[21] W. S. Fang, Y. Lai and S. M. Miller, "Does Exchange Rate Risk Affect Exports Asymmetrically? Asian Evidence," Economics Working Papers, 2005.

[22] K. Mukesh and B. a. N. Azeema, "The Impact of Currency Depreciation on Exports of SAARC Countries," Asian Journal of Economic Modelling, vol. 8, no. 1, pp. 16-29, 2020.

[23] V. Polterovich, V. Pavlov, V. Polterovich and V. Popov, "Accumulation of Foreign Exchange Reserves and Long Term Growth," MPRA Paper 20069, 2006.

[24] N. S. O. o. Georgia, "www.geostat,ge," January 2020 [Online]. Available: https://www.nbg.gov.ge/index.php?m =304).\&lng=eng. [Accessed 28 December 2019]. 